\title{
Multiplicity of History in Our Lady of Alice Bhatti Through Historiographic Metafiction
}

\author{
Ayesha Ashraf $^{1} \&$ Sardar Ahmad Farooq ${ }^{2}$ \\ ${ }^{1}$ English Department, National University of Modern Languages, Islamabad, Pakistan \\ ${ }^{2}$ English Department, Government Post Graduate College Mansehra, Pakistan \\ Correspondence: Ayesha Ashraf, c/o English department, NUML University, Islamabad, Pakistan. E-mail: \\ awan.ayesha@Rocketmail.com
}

\author{
Received: December 1, 2019 Accepted: January 8, 2020 Online Published: January 13, 2020 \\ doi:10.5539/ijel.v10n1p395 \\ URL: https://doi.org/10.5539/ijel.v10n1p395
}

\begin{abstract}
English fiction, in the recent decades, has significantly manifested its deepest concern for postmodern transformation of history through subversion of the traditional historical narratives. The current research paper aims to highlight the postmodern transformation of history in the selected English novel Our Lady of Alice Bhatti written by Muhammad Hanif. The selected novel as postmodern historiographic metafiction highlights that contemporary fiction manifests and retells the traditional history through memory, parody, self-reflexivity and intertextuality. The current research study generates a better understanding of the present interdisciplinary relation of fiction with that of other disciplines especially history. The postmodern theoretical concepts of Linda Hutcheon are incorporated in this current study. This research is qualitative and exploratory, while textual analysis has been used as a research method. This research ends with the findings and recommendations for further research.
\end{abstract}

Keywords: postmodernism, historiographic metafiction, transformation, partition, post-partition

\section{Introduction}

Postmodernism started a debate in literature in 1970's and it emerged as an extension as well as a reaction against modernism. The term "modern" was derived from a Latin word 'modo', that means 'of today' or anything that is current, and different from earlier times. It was used in history to distinguish the contemporary thought, culture, philosophy, trend or society from the traditional one. On the other hand, postmodernism was launched as a widespread cultural development whose significance was acknowledged due to its different treatment of truth, reason, power and language. In fact, it stands for a sense of something completed, ended and over in the thought, culture, and life especially in the second half of the twentieth century. Postmodernism influenced every field of art ranging from music, philosophy, architecture, culture, language, history and literature, hence, in this way it also changed the existing trends. Many theorists such as Nietzsche, Hegel, Jurgen Habermas, Foucault, Lyotard, Hutcheon and Derrida questioned the status of knowledge in relation to various disciplines including philosophy, anthropology, sociology, gender studies, history, politics and psychology. These theorists explored the influence of postmodernism on the condition of knowledge that was actually transformed from the modern thought. They also debated on the postmodern strategy to estrange the reader with the grand narratives such as science, faith, nationalism and history.

Linda Hutcheon, a postmodern theorist and a Canadian scholar, was born in 1947. Currently, she is serving as a professor of English in University of Toronto. In the year 2000, she became the third Canadian woman who was successfully elected as president of MLA (Modern Language Association). Her famous books include $A$ Theory of Adaptation, A Poetics of Postmodernism, History, Theory, Fiction, Irony's Edge, Narcissistic Narrative and A Theory of Parody. She in her book Poetic's of Postmodernism: History, Theory, Fiction coined the term 'historiographic metafiction' for novels which reconstruct past by combining fiction and reality. She discards the notion that fiction is a separate discipline from history rather, according to her, both the disciplines construct realities through discursive strategies. She further asserts that fiction and history are not fixed products but, in fact, both are in a continuous process of making. She calls such postmodern mixture of fiction and history as historiographic metafiction that combines the 'constructedness' and 'story-telling' together. Contemporary Pakistani English novels retell past through various narratives that construct a story of different historical events 
especially partition of subcontinent in 1947.

Muhammad Hanif, a Pakistan based English fiction writer, was born in Okara Pakistan in 1964. He has written novels, some of the famous plays for stage and radio, and a feature film. He is globally recognized for his contribution to Pakistani English fiction. His novels are A Case of Exploding Mangoes (2008), Our Lady of Alice Bhatti (2011) and The Baloch who is not missing and others who are (2014). Themes of his novels revolve around social, political, religious, historical, and cultural issues of Pakistan. His fiction is generally compared with that of Saadat Hasan Manto, Joseph Heller, and Salman Rushdie's work. His novels are well acknowledged not only in the Indian subcontinent but also in the global literary world. His novels have been translated into sixteen languages, in order to facilitate the wider audience beyond borders. Our Lady of Alice Bhatti was nominated for the Welcome Trust Book Prize in 2012, and for DSC Prize for South Asian Literature in 2013. Currently, Hanif resides in Pakistan. Our Lady of Alice Bhatti, as historiographic metafiction, retells partition event and post partition scenario of Pakistan. The Partition of Indo-Pak subcontinent is enthusiastically represented by the fiction writers from both the countries as compare to the traditional historians as Ayesha Jalal and Sugata Bose opine that, "The colossal human tragedy of the partition and its continuing aftermath has been better conveyed by the more sensitive creative writers and artists-for example in Saadat Hasan Manto's short stories and Ritwik Ghatak's films - than by historians" (2004, p. 164).

\subsection{Research Objective}

This study is based on the following objective:

1) To investigate the transformation of history in Our Lady of Alice Bhatti.

\subsection{Research Question}

On the basis of research objective, this study investigates the following question:

1) How does Our Lady of Alice Bhatti, as historiographic metafiction, transform the traditional history?

\section{Literature Review}

The term 'postmodernism' is defined by a variety of interpretations and thus it has created confusion and controversies among different theorists. At present, either it is celebrated or condemned, but it, significantly, represents the contemporary world, and it's influence on an individual's life. The theorists namely Linda Hutcheon, Jurgen Habermas, Ihab Hassan, Jean-Francois Lyotard, Fredric Jameson and Jean Baudrillard have proposed their understanding of postmodernism. Though, their attempts could not define the movement in an absolute way as this trend is currently in practice and ongoing, hence it is always vulnerable to change. Lyotard (1984) states that it is not a new movement rather it emerged after modernism as a consequence of materialistic progress and scientific advancements. He refers to postmodernism as a movement that shows an 'incredulity towards metanarratives' ( $\mathrm{p} . \mathrm{x} \mathrm{x}$ iv) as it challenges the existing perceptions and thought patterns which are based on claims of objectivity and truth. Etymologically the word 'meta' means 'about' and 'narrative' is a story, hence a 'metanarrative' is actually 'a story about a story'. Lyotard's theory of mini narratives questions all ideological constructs of modernism, and he regards this new condition of knowledge as a 'postmodern condition.' According to him, metanarratives as modern ideological constructs, totalize a system of knowledge and, in this way, create a clash between modernism and postmodernism. Linda Nicholson (2013) comments, "In Lyotard's view, a metanarrative is meta in a very strong sense. It purports to be a privileged discourse capable of situating, characterizing, and evaluating all other discourses" (p. 22).

Historical events and momentous happenings are one such domain, which have been mirrored in the literature, mostly through treatises, essays, and, of course through novels. Moreover, postmodern fiction does not record the conventional dry description of 'authentic' history along with reference towards its exact dates, places or events rather it incorporates the elements of fancy and imagination which also add color to the story/history. In 19th and 20th centuries, history and literature were thought to be two separate domains, but, postmodern fiction contested this rigid compartmentalization. In fact, postmodern history is different from the nostalgia that retells and admires the pleasant past events, on the contrary historiographic metafiction laments at the tragic history that has not only destroyed the past but it still influences the present. Catherine Belsey (1994) states, "The fictional problematization of history of our access to the 'facts' is so common in recent novels that Linda Hutcheon has coined the term 'historiographic metafiction' and treat it as the paradigm case for postmodern fiction" (pp. 683705). Historiographic metafiction challenges the conventional and ordered representation of history as, in reality facts exist in discontinuity, as:

In fact, that teller-of story or history—also constructs those very facts by giving a particular meaning to events. Facts do not speak for themselves in either form of narrative: the tellers speak for them, making 
these fragments of the past into a discursive whole. (Hutcheon, 1988, p. 73)

Partition is still a controversial and it is interrogated in contemporary time in terms of its validity, necessity, objectivity, and consequences. The official history, of Pakistan and India, emphasizes more on grand narrative of freedom than on partition, in fact it glamorizes the role of political leaders who were involved in this decision. Partition (1947) divided them into two separate countries i.e., the Islamic Republic of Pakistan, and Republic of India. The British government could have attempted to bridge the differences between the two in order to make them united, but it did not do so. Muhammad Qadeer (2006) states that, "The differences were further sharpened by the British colonial policy of classifying people by ethnicity and caste" (p. 7). Though, different Hindu leaders like Gandhi, Motilal Nehru, Jawaharlal Nehru, C. Raja Gopal Achari and Tej Bahadur Sapru were in favor of Hindu Muslim unity. Sir Syed Ahmad Khan motivated Muslims to learn English, he also motivated them to stay loyal towards the British government, and to promote a united nation. The problem was created because of this perception that as Muslims are in the majority so it is only their right to rule and be heard as "One of the unique aspects of the creation of the nation of Pakistan is that the political party that dominated the negotiations for independence, the Muslim League, automatically assumed leadership in the new nation. As a result, the League's version of Muslim nationalism became Pakistan's prevailing nationalism" (Cilano, 2013, p. 4).

Traditional history records three perspectives of government, anti-government and separatist groups while, at the same time, it neglects the stories of common people who have suffered in traumas. Various academicians, scholars, novelists and students write about partition as it is still relevant to the present decisions and policies of both the countries i.e., Pakistan and India. Our Lady of Alice Bhatti explores the transformation of history through highlighting de-mystification and re-interpretation of the past. The novel links history with the present, as the characters compare personal and political past with the present. Its re-writes partition and post-partition period. Our Lady of Alice Bhatti decentralizes modern novel as it incorporates multiple narrators in the main discourse. Significant postmodern notions such as; 'Death of Author' and 'Role of Reader' are evident through the use of strategies like open conclusion, fragmentation, magical realism, and multi layered stories. Our Lady of Alice Bhatti reflects on the ongoing uncertainty and insecurity of Karachi as Stuti Khanna (2016) states that:

The casually, gratuitously, almost absurdly violent Karachi that Mohammed Hanif's Alice belongs to (Our Lady of Alice Bhatti, 2011) could be straight out of a Quentin Tarantino film, except that it refers to a very real, very contemporary city that is struggling with sectarian violence, extremist groups and organized crime mafias that work more often than not in cahoots with a woefully inadequate police force (p. 103).

Muneeza Shamsie (2017) in Pakistani-English Writing states that, "Hanif's Our Lady of Alice Bhatti (2011) is a very different work, a black comedy centered on Pakistan's Christian minority and the hospital wards of violent Karachi" (n.p). The novel laments at post-partition discrimination and marginalization of minority community in Pakistan. In fact, Muhammad Ali Jinnah, founder of Pakistan, in his inaugural speech to the Constituent Assembly in Karachi on 11 August 1947 stated, "You are free; you are free to go to your temples, you are free to go to your mosques or to any other place of worship in this state of Pakistan. You may belong to any religion or caste or creed - that has nothing to do with the business of the state" (Wolpert, 1984, p. 337). Ironically, this speech is not followed by the citizens as the novel laments at post-partition miserable status of Christians, that as minority they are leading a miserable life. Bina Shah (2014) comments on Hanif's novel:

Our Lady of Alice Bhatti (2011) traces the life of a Punjabi Christian nurse living and working in modern-day Karachi-captures the vernacular of the Punjabi Christian community, the Bollywood influenced, oath-laden talk of Karachi's police forces, and the flowery language of the Anglo-Indian Christian clergy (n.p).

\section{Research Methodology}

The present study is descriptive and qualitative. The data comprises of one novel Our Lady of Alice Bhatti, and textual analysis is used as a research method that focuses on the minutest details of the text. The selected text is studied in different components like words, sentences, phrases and idioms. The research is organized and carried systematically through divisions i.e. introduction, literature review, textual analysis, conclusion, findings and references. Catherine Belsey's "textual analysis" has been used as a research method that focuses each and every word in order to look beyond the literal meaning. Belsey in her essay "Textual Analysis as a Research Method" states:

Any serious textual analysis depends on a grasp of how meaning works. Meaning, then, subsists in the relations between people, inscribed in signifiers, sounds or images including written shapes and pictures. It has its own materiality: meaning intervenes in the world, defining our understanding of values, requiring us 
to obey rules and, indeed, calling us to arms (p. 167).

\section{Textual Analysis of Our Lady of Alice Bhatti}

\subsection{Partition}

Our Lady of Alice Bhatti retells the partition event from the perspectives of common men. Hanif incorporates multiple stories about the partition and historical characters. The commentary on and through various characters reveals the trauma of partition as, "Teddy kneels beside him and wriggles his hand into the left pocket of PT teacher's shorts. His shorts are frayed but made of expensive cotton material. Butter Jeans, he likes to call them; apparently the only factory that made them was burnt down during partition" (p. 199). These lines reflect the immense loss that partition did to the property and business, other than killing innocent human beings. It came with massacre, bloodshed, misunderstandings, and injustice, and, sadly, this side of the tragedy is not reflected by official historians. In fact, the exclusion of some sections not only affects the true history, but it also fails to acknowledge the existence of the people who, in reality, have suffered during historical tragedies. During partition, millions of Hindus and Muslims were killed as the novel writes:

For Teddy's father, everyone who was born after Partition was a sissy puss, because nobody quite met his criteria of not being a sissy puss: how much buffalo's milk had they drunk? Had they ever been injured in a real bull race? Had they ever bicycled three hundred miles to watch a Shanta Apte film? Had they ever stolen a government horse? Hell, had they ever stolen anything? And no, electricity didn't count; you were still a sissy puss (p. 202).

The novel, unlike official history, pens down the stories of rapes, lootings, and killings during the riots. It reflects on partition 1947 as a tragic event and emphasizes that, "The thrill of the joy at the end of long and horrible struggle was lost into the tears and pains which emerged suddenly on the face of the nation owing to the sudden but tragic outburst of communal violence in the wake of the partition" (Qadeer, 2006, p. 212). The characters show their fear of a possible recurrence of horrific incidents of past in the future. Sister Hina, one of the characters in the novel, narrates a story related to partition. She tells that after the division; both Pakistan and India mutually agreed to a horrific exchange of mentally retarded Muslims of India to Pakistan; and Hindu patients of Pakistan to India.

The novel refers towards famous historical personalities like Fatima Jinnah and Gandhi. It happens that when Teddy traces the lines, in the hands of Alice, in order to tell her fortune. During their conversation, he draws attention towards a famous historical personality of India, "I have never seen such a generous hand. And this thumb, such willpower, leadership qualities, stubborn maybe. This is definitely a Gandhi hand. Always principles over pleasure" (p. 51). Mahatma Gandhi was a great politician, social activist, moralist, spiritualist, and a philosopher of India. He was famous for his principles of morality, religion, humanity and social values. Teddy's comparison between the personalities of Alice and Gandhi fuses past with the present. The nurse, Hina, narrates that Begum Qaz is treated in the same VIP ward of the Sacred Hospital, where Fatima Jinnah was once treated. Through the mouthpiece of Sister Hina, Hanif provides comments on Fatima Jinnah; "Did you know that Fatima was a dentist, a trained dentist? But she sacrificed her whole life for this country" (p. 79). Sister Hina gives a new dimension to the description of historical character as Hutcheon in A Poetics of Post-modernism identifies the very characteristic of historiographic metafiction that changes the historical facts, and it aims to "to foreground the possible mnemonic failures of recorded history and the constant potential for both deliberate and inadvertent error" (p. 83). In fact, this technique destabilizes the reader's knowledge of fixed historical facts and presents to him an optional course of history. Therefore, Hina challenges the stereotypical labeling of Fatima Jinnah as 'mother' and she says:

What do you call them: mother of nation. Now if her brother is the father of the nation, how can she be the mother of the nation? They could have called her sister of the nation, but no. Because then people might have mistaken her for a nurse, one of us. It's a nation of perverts, I tell you (p. 118).

The above lines manifest that partition did not only affect the people who witnessed it, but also, it cast an impact on those who did not witness it, like the younger generations of the victims. Sister Hina, also, criticizes the Pakistani nation by calling them 'perverts, and she relates the horrible tragedy of 1947 with the current moral chaos of society. Her personal commentary makes the novel a work of metafiction as it "calls attention to its representational techniques and knowledge claims" (Duvall, 2012, p. 15). In this way, the novel makes the reader realize that though the events of history have become an event of past but they are quite relevant, in their effect, to shape the contemporary social, psychological, and emotional attitude of people. 


\subsection{Post-Partition till Present}

The novel laments at the post-partition state of Pakistan that, even after gaining independence, it is still confronting with never ending issues and problems. It highlights on the fact that several problems of current day Pakistan have roots in the partition 1947 event. The fact, that Alice Bhatti and her father Joseph Bhatti are marginalized just for the reason that they are Christians and belong to minority, has its roots even before the period of partition. The novel draws a comparison between the pre-partition, partition and post-partition unstable states as it states, "Alice follows her gaze towards the ceiling and sees a wet patch that looks like a map of a country in transition" (p. 76). These conversations, incidents and commentaries draw the reader's attention towards the current social, cultural and political situation of Pakistan, and it turns ironic at the fact that the country could not get rid of problems even after gaining independence. Similarly, many characters, in the novel, reflect the same distrust over the current situation of Pakistan for instance, when Alice, in a conversation with Teddy, expresses her grave concern for his police job as it is an unsafe and risky job. Teddy replies her that, "We live in dangerous times. We live in a dangerous place. It's better to know the danger, to work with it, to tame it" (p. 131). These lines, taken from the text, sensitize the reader about the current serious situation of the country, and help reader to understand and play his role in order to make this world a better place to live in. The novel, in a subtle yet ironic way, relates past with the present, and it also reveals the sectarian biases prevailing in the country that was made in the name of unity. Alice, once, falls in love with a famous gynecologist. She even gets pregnant with his child, and she discloses her pregnancy with the father of the child. At first, he gets excited and starts planning as, "First he started to cry, then he chain-smoked for an hour and went through a list of baby names that included every possible combination from the names of the central executive committee of the Indian Communist Party at the time of Partition" (p. 123). The lines reflect that even in the present time, when long decades have been passed since the creation of Pakistan, people are still influenced by this event and their most of the actions are based on this historical event.

Our Lady of Alice Bhatti retells the history of various political events in order to find "The Presence of the Past" (Hutcheon, 1989, p. 3) and their relation with the religions i.e. Islam and Christianity. Hanif, being a writer and an ex-journalist for BBC News London, focuses on the description of the minutest details. Through the character of Joseph Bhatti, it comments on the history of the cross as he says that, "I have been working on a cross, the world needs this one. You know that our Lord Yassoo's faith didn't spread beyond Egypt until they learned to mass-produce wooden crosses. What we need to do is make our own" (p. 107). Joseph Bhatti, besides telling the history of the cross, also highlights the history of his Christian community in Pakistan, he says, "Choohras were here before everything. Choohras were here before the Sacred was built, before Yassoo was resurrected, before Muslas came on their horses, even before Hindus" (p. 126). The novel portrays a poor state of minority, represented by Alice and Joseph, who is not given any identity even in a free country that was made on the slogan of freedom. Mubashar Altaf and Qaiser Shehzad (2019) state:

She is a strong subaltern who faces intolerant Muslim girls at the nursing school, she tolerates her stay in the Borstal jail, and she faces the court and justice system of the society as a revolutionary figure. Hanif painted the biased and intolerant attitude of the society against the Christian minority. She is considered a worthless species in this established system (p. 69).

The secondary characters also comment on the history of Pakistan as Noor, a young boy and a lower staff at the Hospital, refers to a newspaper when he asks Alice about her marriage. The text writes it as, "Noor does not ask her who and why; he is more concerned about where. He has heard that she got married on a nuclear submarine, Pakistan does not have nuclear submarines, he knows that, he has read it in the papers" (p. 179). These textual lines show that Teddy is not sure about the record of submarines and he is just constructing it in a clear manner and this refers to another feature of historiographic metafiction. Hutcheon (1988) calls it as assimilation of historical data as she states, "historiographic metafiction incorporates, but rarely assimilates such data. More often, the process of attempting to assimilate is what is foregrounded" (p. 111). These lines show that along with the personal commentary; the novel discusses rules and regulations of certain departments. Sister Hina criticizes the prevailing stereotypes and she also traces their links in history and in this way reminds us "of the need to question received versions of history" (p. 115). Sister Hina says:

I don't know what this world is coming to, as a child, I was taught that God is in everything. Now that I am getting old, they want me to literally see God in vegetables. For the last five years, every year there is an aubergine somewhere that, when you slice it, it has the word Allah running through it (p. 226).

She mocks at the superficial approach of the common people who bring religion in every matter of life, instead of truly following it. In this way, textual analysis of the novel highlights that various character do challenge the 
grand narrative of history in order to demonstrate postmodern multiplicity of histories.

\section{Conclusion}

The present study has evaluated Our Lady of Alice Bhatti as historiographic metafiction, and it has found that the selected novel does represent partition and post-partition narratives in the light of personal narratives. The selected novel decentralizes and contests the great historical tales through the mouthpiece of various peripheral characters such as minority and women. The novel problematizes the difference between fact and fiction by blending history and constructed fictional stories. The present study concludes with the findings that the selected novel Our Lady of Alice Bhatti can be labeled as a historiographic metafiction due to the presence of multiple history(s) that subvert the traditional absolute, progressive and universal history. The presence of various characters and their multiple stories challenge historical objectivity, authenticity and authority over truth. Similarly, the emerging English fiction authors are exploring the postmodern connection between past, present and future that needs to be highlighted in future research in order to move forward to a healthy and sensible society.

\section{Acknowledgments}

We are sincerely thankful to the constant support of our teachers for making us conduct this research from a unique dimension related to history and its relation with literature. We would like to acknowledge the valuable suggestions that we received from our colleagues and senior fellows regarding important sections of this paper.

\section{References}

Agrawal, B. R., \& Sinha, M. P. (2003). Major Trends in the Post-Independence Indian English Fiction. Atlantic Publishers \& Dist.

Altaf, M., \& Shahzad, Q. A. (2019). Subaltern's Quest for Identity and Respect: A Gramscian Study of 'Our Lady of Alice Bhatti'. International Journal Online of Humanities, 5(6), 62-74. https://doi.org/10.24113/ijohmn.v5i6.152

Belsey, C. (1994). Postmodern Love: Questioning the Metaphysics of Desire. New Literary History, 25(3), 683705. https://doi.org/10.2307/469473

Belsey, C. (2013). Textual Analysis as a Research Method. Edinburgh: Edinburgh University Press.

Bose, S., \& Ayesha, J. (2004). Modern South Asia: History, Culture, Political Economy. New Delhi: Oxford University Press. https://doi.org/10.4324/9780203712535

Cilano, C. N. (2013). Contemporary Pakistani Fiction in English: Idea, Nation, State. Routledge. https://doi.org/10.4324/9780203552247

Duvall, J. N. (Ed.). (2012). The Cambridge Companion to American Fiction After 1945. Cambridge University Press. https://doi.org/10.1017/CCOL9780521196314

Hanif, M. (2011). Our Lady of Alice Bhatti. Random House.

Hutcheon, L. (1989). Historiographic Metafiction: Parody and the Intertextuality of History. Johns Hopkins University.

Hutcheon, L. (2003). A Poetics of Postmodernism: History, Theory, Fiction. Routledge. https://doi.org/10.4324/9780203358856

Khanna, S. (2016). Writing the Margins (in English): Notes from Some South-Asian Cities. In South-Asian Fiction in English. Palgrave Macmillan, London. https://doi.org/10.1057/978-1-137-40354-4_6

Lyotard, J. F. (1984). The Postmodern Condition: A Report on Knowledge (Vol. 10). University of Minnesota Press. https://doi.org/10.2307/1772278

Nicholson, L. (2013). Feminism/postmodernism. Routledge. https://doi.org/10.4324/9780203699386

Qadeer, M. (2006). Pakistan-social and Cultural Transformations in a Muslim Nation. Routledge. https://doi.org/10.4324/9780203099681

Rao, V. P. P., Rani, K. N., \& Rao, D. B. (2004). India-Pakistan: Partition Perspectives in Indo-English Novels. Discovery Publishing House.

Shah, B. (2014). Literature: The antidote to the Pakistani identity crisis. The Journal of Commonwealth Literature, 49(1), 3-10. https://doi.org/10.1177/0021989413513984

Shamsie, M. (2017). Pakistani-English Writing. In Oxford Research Encyclopedia of Literature. 
https://doi.org/10.1093/acrefore/9780190201098.013.69

Wolpert, S. A. (1984). Jinnah of Pakistan. New York: Oxford University Press.

\section{Copyrights}

Copyright for this article is retained by the author, with first publication rights granted to the journal.

This is an open-access article distributed under the terms and conditions of the Creative Commons Attribution license (http://creativecommons.org/licenses/by/4.0/). 